\section{A Backward Step in Forest Research}

It was a most unpleasant surprise for foresters, scientists and technicians of the Canadian Forestry Service to find that the threatened reductions in staff were being carried out, when many received notice of dismissal on December 10, 1969. Among more than 150 so advised, many were career research foresters of long standing with established scientific reputations. We sincerely hope that much thought was given to improving efficiency before the above measure was carried out. To the best of our knowledge, neither the administrative portion of the Service nor any of the employees of the Department of Fisheries are affected.

This staff reduction follows a request by the Canadian Institute of Forestry to the Honourable Jack Davis, Minister of Fisheries and Forestry, (For. Chron. Dec. 1969, p. 466) for assurance that, if at all possible, savings would be made within the Department as a whole, without dismissal of highly qualified members of the staff and consequent disruption of important research projects. This assurance was not given.

The reduction comes at a time when more research is needed than ever. Certain studies, particularly those dealing with some basic problems in forest biology, have been abruptly terminated. We have always looked upon the work done by the Federal Government as having a definite chance of continuity and being brought to a fruitful conclusion.

In the past twenty years, the Federal Forestry Branch has had many difficult moments, having been shunted from one department to another, having had its name changed, and losing priority in the process. Consequently, staff morale has been greatly affected and is now probably at an all time low. Some forest research workers have resigned either in protest, disgust or despair. Others may very well do the same in search of a better work environment.

Just a few years ago, the Department of Forestry seemed to grasp the great need for research and went through a rapid staff buildup. Unable to find in Canada the necessary scientists, it scoured the world in search of qualified researchers. It may be assumed that this move resulted in part in a greater interest in post-graduate studies in Canadian universities by graduate foresters. Not only will this new interest be adversely affected but also there will probably be real difficulty in attracting well-qualified scientists into the Service in future.

This oscillation between expansion and contraction, is not conducive to productive forest research. Research, particularly forest research, needs long term budgeting and consistent and sound administration, if ideas and techniques are to be pursued by well-motivated and curious workers. The present cut-back would seem to make it very difficult for the Federal Government to provide this environment. If such be the case it would be preferable to have a much larger portion of any increases in its budget used for the support of university and industrial forest research.

François Matte, President, Canadian Institute of Forestry
Editor

G. F. Weetman

570 St. John's Rd.,

Pointe Claire, P.Q.

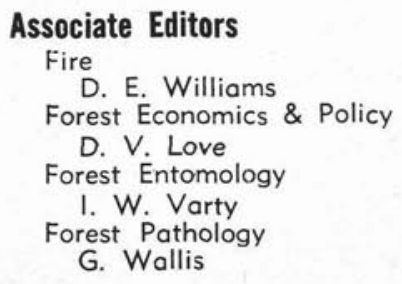

Forest Products

R. H. J. Creighton

Forest Management

G. F. Weetman

Logging
H. I. Winer
Silviculture
R. J. Day
D. Glew
Wildlife
D. H. Pimlott
French Associate Editor

H. LeBlanc
Published bi-monthly by the Canadian Institute of Forestry - Institut Forestier du Canada. Address all correspondence concerning business matters to $\mathrm{A}$. 5000, Macdonald College, P.Q., Canada. 5000 , Macdonald College, P.Q., Canada. Subscription rates $\$ 10.00$ per year in single copies, Return postage guaran single copies. Return postage guaranthe The Institute assumes no responsibility pressed by contributors. There is a $\$ 40$ per page charge for articles on the results of research. This charge is only made when the supporting agency has allocated funds for publication. 